\title{
Fibrosis in Chronic Kidney Disease. Protagonista and Therapy
}

\author{
Laura S. Villanueva1*, Begona Santos S. Rey ${ }^{2}$ \\ ${ }^{1}$ Department of Nephrology, Hospital universitario de la Princesa, Madrid, Spain \\ ${ }^{2}$ Begoña Santos Sanchez Rey, Department of Nephrology, Hospital universitario de la Princesa, Madrid. Spain
}

Received: August 9, 2016; Accepted: August 12, 2016; Published: August 21, 2016

*Corresponding author: Laura Salanova Villanueva, Department of Nephrology, Hospital universitario de la Princesa, Madrid, Spain, Tel: +605645894; Email: aelita.sv@gmail.com

\begin{abstract}
Chronic kidney disease is a serious public health problem, for its high incidence and prevalence and its significant morbidity and mortality. Fibrosis is the end of all impaired renal failure. The fibrotic process is characterized by infiltration of inflammatory cells ( $\mathrm{T}$ cells, macrophages etc), cytokine releases, activation of fibroblasts and activation of numerous chemical signals. This process involves effector cells generation which produce extracellular matrix leading to organ damage. No therapy has demonstrated efficacy $100 \%$ against fibrotic damage. Vitamin D and its analogues can exert their immunomodulation through the regulation of the activity of many types of immune cells and present an ant fibrotic profile.
\end{abstract}

Keywords: Fibrosis; Chronic kidney disease; Epithelial mesenchymal transition; Vitamin D

\section{Introduction}

Nephron is kidney functional unit. It composed of glomerulus, Bowman's capsule, a complex tubular network, the interstitium, juxtaglomerular apparatus and a complex interweaving of vessels. Glomerulus is responsible for plasma ultrafiltrate formation $[1,2]$.

Tubule-interstitial network represents $80 \%$ of renal volume. This network consists in $[1,2]$ :

- Interstitial cells type I: fibroblasts like that are responsible for the synthesis and

- Degradation of Extracellular Matrix (ECM).

- Interstitial cells type II: monocyte-derived macrophages and dendritic cells.

- Matrix: collagen, proteinglicans, glycoproteins, interstitial fluid.

- Tubular cells: responsible for substances transport.

- Specialized cells: juxtaglomerular cells: reninproducing, tubular cells which produce active vitamin D, erythropoietin, Klotho.
Kidney aggression leads to an inflammatory and reparative response which could lead in a fibrotic response that carries permanent kidney damage. Here we review fibrosis process in the kidney and signals and molecules that could influence in this process as well as potential therapeutic drugs.

\section{Fibrosis process in Chronic Kidney Disease (CKD)}

Progressive fibrosis is the final common pathway for all kidney diseases leading to chronic renal failure. Its presence correlates with impaired excretory function and the degree of fibrosis or fibroblasts number are markers of progression ${ }^{3}$. Chronic infections, toxic and metabolic injuries, and idiopathic inflammatory diseases can promote the development of fibrosis [3]. Renal disease offers a favorable microenvironment for fibrotic process: increased cytokines and inflammatory substances, profibrotic growth factors, ECM deposition: collagen type I, III, IV, proteoglycans and fibronectin [3,4], reactive oxygen species (ROS) [3] etc. Cytokines act as pleiotropic polypeptides synthesized by different types of cells, causing paracrine, yuxtacrin and autocrine effects which can regulate immune and inflammation response [5].

These factors accelerate programmed cell death (apoptosis), an inflammatory process that involves fibrosis and an alteration of cell profile in glomerular and tubular interstitial cells. Cells undergo a phenotypic conversion called Epithelial-Mesenchymal Transition (EMT), although there are studies that question this process in the kidney and consider that the process of fibrosis is not because EMT [3-7]. Fibroblasts and myofibroblast also increase which caus matrix-production.

Fibroblasts are key mediators of fibrosis in the kidney and other organs, but their origin is still not completely clear [3]. Activated fibroblasts likely arise from resident quiescent fibroblasts via epithelial-to-mesenchymal transition and from the bone marrow. Fibroblast is a connective tissue cell derived from mesenchymal stem cells or leukocyte, it could secrete different proteins such as procollagen, and proteglycans to form part of ECM $[8,9]$. Myofibroblast is a special fibroblast that has developed some smooth muscle cells characteristics that 
can express $\alpha$-smooth muscle actin ( $\alpha$-SMA), fibronectin ED-A, adhesion molecules, CD31, collagen I and other mesenchimal cells markers [9] (Table 1). Myofibroblasts and fibroblasts could join to estrogen and steroids receptors, vitamin D and growth factors [9], and in the kidney could express erythropoietin [9].

Glomerular podocytes undergo phenotypic conversion, characterized by loss of podocyte-specific markers and gain of transitional features, a process reminiscent of EMT; proteinuria is a clinical manifestation of this process [3-6]. However tubulointerstitial fibrosis is better correlated with renal damage than glomerular fibrosis [3].

We expose changes in glomerular and tubular network due to the fibrosis process in (Figure 1).

\section{Epithelial mesenchymal transition}

EMT is a process where differentiated epithelial cells undergo a phenotypic conversion that involves fibroblast and myofibroblast matrix-producing, it is recognized as an integral part of tissue fibrogenesis after injury [6-10]. EMT concept was formulated in embryonic development and in tumor metastases. Tubular and glomerular renalcells lose their epithelial phenotype and acquire new characteristic features of mesenchymal cells [6$10]$; it is a potentially reversible process.

Epithelial cells lose their phenotype and markers such as E-cadherin, Zonula ocludens 1 (ZO-1) etc and acquire new characteristic features of mesenchyme such as $\alpha$-SMA, vimentin, CD31, collagen I, fibronectin [7-10]. Glomerular cells podocytes are specialized visceral epithelial cells also undergo EMT under pathologic conditions. Upon incubation with transforming growth factor $\beta$ (TGF- $\beta$ ), reduce the slit diaphragm-associated proteins $\mathrm{P}$-cadherin, ZO-1, and nephrin and begin to express the intermediate filament protein desmin, secret MMP-9, produce the interstitial matrix components and up regulate the transcription factor Snail. As a result, these alterations impair podocytes' filtration barrier function, and proteinuria can be induced [11]. Damage to tubular epithelial cells produce various chemokines

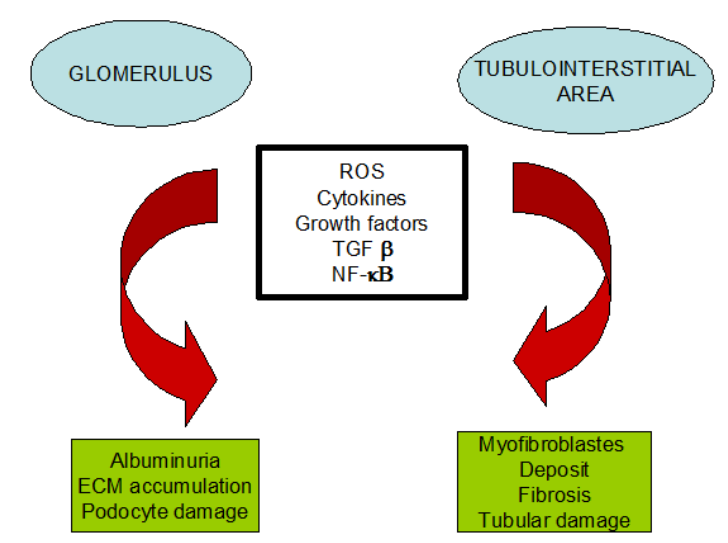

Figure 1: Fibrosis Consequences in Glomerulus and Tubulointerstitial Area; ROS: Reactive Oxygen Species; TGF- $\beta$ : Transforming Growth Factor $\beta$; NFkB: Nuclear Factor $\kappa$ Beta
Table 1: Cells marker; HSP47: Shock Hot Protein 4; ICAM: Intracellular Adhesion Molecule 1; $\alpha$ SMA: $\alpha$ Smooth Muscle Actin; DDR2: Diiscoidin Domain Receptor 2; NG2: Neuroglial Antigen 2; PDGFR: Platelet Derived Growth Factor; FSP1: fibroblast specific protein 11.

\begin{tabular}{|c|c|c|c|c|}
\hline \multicolumn{3}{|c|}{ Cell Types } & \multicolumn{2}{|l|}{ Cells markers } \\
\hline \multicolumn{3}{|c|}{ Fibroblasts } & \multicolumn{2}{|c|}{ FSP1, HSP47, C44, ICAM, DDR2 } \\
\hline \multicolumn{3}{|c|}{ Myofibroblasts } & \multicolumn{2}{|l|}{$\alpha$ SMA } \\
\hline \multicolumn{3}{|c|}{ Pericites } & \multicolumn{2}{|c|}{$\alpha$ SMA, NG2, PDGFR2, Desmin } \\
\hline \multicolumn{3}{|c|}{ Vascular smooth muscle cells } & \multicolumn{2}{|c|}{$\alpha$ SMA, calponin, caldesmon } \\
\hline \multicolumn{3}{|c|}{ Mesenchimal stem cells } & \multicolumn{2}{|l|}{ FSP1 } \\
\hline \multirow{7}{*}{ TGF $\beta$} & \multirow{3}{*}{ Glomerulus } & \multicolumn{2}{|c|}{$\begin{array}{l}\text { Podocyte apoptosis: } \\
\text { - Podocyte depletion } \\
\text { - Glomerular tuft adhesión }\end{array}$} & \multirow{3}{*}{$\begin{array}{l}\text { Glomeruloscle- } \\
\text { rosis }\end{array}$} \\
\hline & & \multicolumn{2}{|c|}{$\begin{array}{l}\text { Endothelial cells apoptosis: } \\
\text { - Decrease endotelial cell } \\
\text { survival } \\
\text { - Glomerular capillary loss }\end{array}$} & \\
\hline & & $\begin{array}{l}\text { Mesang } \\
\text { - EMC a }\end{array}$ & $\begin{array}{l}\text { l cell activation: } \\
\text { cumulation }\end{array}$ & \\
\hline & \multirow{4}{*}{$\begin{array}{l}\text { Tubulointer- } \\
\text { stitial area }\end{array}$} & $\begin{array}{l}\text { Epithel } \\
\text { - Tubul } \\
\text { - Tubul }\end{array}$ & $\begin{array}{l}\text { l cells apoptosis: } \\
\text { degeneration } \\
\text { atrophy }\end{array}$ & \multirow[b]{4}{*}{$\begin{array}{l}\text { Tubulointers- } \\
\text { ticial } \\
\text { Fibrosis }\end{array}$} \\
\hline & & $\begin{array}{l}\text { EMT: } \\
\text { - Tubul } \\
\text { - Fibrol }\end{array}$ & $\begin{array}{l}\text { degeneration } \\
\text { ast activation }\end{array}$ & \\
\hline & & $\begin{array}{l}\text { Fibrobl } \\
\text { - ECM a }\end{array}$ & $\begin{array}{l}\text { t activation: } \\
\text { cumulation }\end{array}$ & \\
\hline & & \multicolumn{2}{|c|}{$\begin{array}{l}\text { Tubular degeneration: } \\
\text { - Endothelial survival decrease } \\
\text { - Tubular atrophy } \\
\text { - Peritubular capillary loss }\end{array}$} & \\
\hline
\end{tabular}

and cytokines secretion in response to stresses (glucose, hypoxia, ROS, autoimmune reaction etc), this process attract inflammatory cells (monocytes, macrophages and lymphocytes) to the tubulointerstitial aerea creating a microenvironment in which cells modify their phenotype for the sake to avoid apoptosis [11].

Different growth factors and cytokines such as TGF $\beta$, connective tissue growth factor (CTGF), nuclear factor $\kappa$ Beta (NF-B) assist EMT process. E-Cadherin reduction plays a central role in mesothelial cells (MC) EMT [12]. An important E-Cadherin repressor is transcription factor Snail, infact Snail is a potent EMT inducer and vitamin D receptor (VDR) inhibitor [13].

A similar process occurs in Peritoneal Membrane (PM) on Peritoneal Dialysis (PD) patients. Peritoneal MCs suffer a disruption of intercellular junctions and loss of the apicalbasolateral polarity of epithelial cells, finally cells are transformed into fibroblast like cells with increased migratory, invasive, and fibrogenic features [14]. This process is due to continuous exposure to bioincompatible dialysis fluids, peritonitis, hemoperitoneum which causes progressive fibrosis and angiogenesis and, ultimately, ultra filtration failure $[14,15]$. EMT not only affects to MC but also to adiposities, leukocytes, fibroblasts and peritoneal vascular cells. 


\section{Inflammatory and fibrosis relevant signals}

T helper 17 cells (THC17) / interleukin (IL) 17: represent $\mathrm{T}$ helper cells subsets that secrete IL specially IL17 and other cytokines. They have been associated with autoimmune and chronic inflammatory diseases [16]. There is an equilibrium between THC17 cells and regulatory T cells; this balance relies on RORyt (Transcription factor retinoic acid receptor-related orphan receptor $\mathrm{t}$ ), Stat 3 and 5 (transduction and activator signal 3 and 5) and FoxP3 (forkhead box P3). In this way immune response is regulated by pro and anti inflammatory cytokines [17-19]. The most important cytokines that regulate balance of regulatory T cells and THC17 are TGF- $\beta$ and I 6 [20]. THC17 cause cytokines secretion (IL6, IL17 A-17F, IL 22) which could trigger an inflammatory process. Among these cytokines 17A represents a greater inflammatory effect and promotes collagen synthesis in fibrosis models [21]. On the other hand, regulatory $\mathrm{T}$ cells, dropped in CKD, prevent fibrocytes and collagen accumulation in different experimental models and their blockade could increase fibrosis risk and organ damage [21].

TGF- $\beta$ : TGF- superfamily consists of secreted peptides, of which the three TGF- $\beta$ isoforms, $(1,2,3)$, activins, and bone morphogenetic proteins (BMP) are best known. The TGF- $\beta$ isoforms are widely expressed and act on every cell type in mammals by engaging a ubiquitous intracellular signaling cascade of Smad family proteins [22]. In cell nucleus receptoractivated Smad (especially Smad 2, 3) protein complexes participate in transcriptional activation of target genes related to fibrosis, inflammation and EMT [22]. TGF- $\beta$ is considered one of the most important regulator of cell proliferation, differentiation, apoptosis, immune response, and ECM generation [11,22]. It is essential in EMT process, both tubular and glomerular [11]. Besides TGF- $\beta$ and S mad 7 together could induce apoptosis in vitro [23]. Regardless of $S$ mad signal, TGF $\beta$ can regulate fibrosis and EMT through other signals such as RhoA protein (Ras homolog gene family member A), MAPK [24 ] (Mitogen activated protein kinase) etc. Tubular atrophy and interstitial fibrosis could be induced by a high protein content in the ultrafiltrate, and this process can generate an inflammatory reaction [26]. EMT, induced by TGF- $\beta$, could transform tubular epithelial cells into activated Myofibroblasts which involve an increase in ECM [26]. TGF- $\beta$ upregulation implies a decrease in BMP and S mad $1,5,8$ [27]. Besides TGF- $\beta$ increase involves vascular damage: mesenchimal stem cells have the ability to differentiate into osteoblast cells in response to an inflammatory process, in which TGF- $\beta$ is activated and up regulated. So TGF- $\beta$ stimulates the mobilization of mesenchimal stem cells from bone marrow to blood circulation to the injured sites for vascular repair and remodelling $[28,29]$.

TGF $\beta$ can be stimulated by[22]: leptin, different cytokines, IL1 (increases their actions not their expression); and is inhibited by vitamin D and its analogs, celecoxib, BMP 7 and hepatocyte growth factor among others[27].

TGB- $\beta$ effects over the kidneys summarized in (Table 2).

Smad family proteins: Smads are intracellular proteins that transducer extracellular signals from TGF- $\beta$, BMP and other to the nucleus where they activate downstream gene transcription [30]. Smad 2 and 3 transduce TGF- $\beta$ signal; Smad 1, 5 and 8 mediate BMP 7 signal. Smad 2, 3 and 4 over expression in murine cells produce fibrosis [30]. Smad 7 inhibits NF- $\kappa B$ nuclear translocation process and function, NF- $\kappa \mathrm{B}$ activate transcription genes with anti-apoptotic functions [31]. At nuclear level, Smad repressors are SnoN (Ski novel gene-related, non Alu-containing) and Ski (Sloan-Ketetering proto-oncogene Institute) [32]; their levels drop down during advance fibrosis damage [33].

BMPs: these proteins are part of the TGF superfamily [33]; at least, there are 30 BMPs proteins named for their osteoinductive properties that have important roles in organogenesis in a variety of tissues [33]. BMPs act by binding to a heterodimeric complex of transmembrane receptors (BMP receptor I and II), and signalling results from gene transcription stimulated through phosphorylation and nuclear translocation of regulatory Smad transcription factors [33]. The expressions of BMPs have been described in atherosclerotic plaques, vascular smooth muscle cells (VSMC) etc [34-36]: BMP 2, BMP 4, and BMP 6 have been localized to areas of vascular calcification. BMP 2 has been the most studied member of the BMP family in vascular calcification process. BMP 2 is expressed in atherosclerotic plaques [34-36] and has been shown to inhibit VSMC proliferation, relate to oxidative stress, inflammation and hiperglucemia [37].

On the other hand, BMP 7 plays a key role in mesenchymal cells transformation into bone and cartilage. Kidney is the most important site for BMP 7 synthesis and expression: glomerular podocyte and distal nephron [38]. Therefore, it is expected that in renal injury animal models BMP 7 is down regulated $[39,40]$. In contrast to BMP 2, BMP 7 has been shown to promote the VSMC phenotype [41,42]. BMP 7 is also important in renal homeostasis by inhibiting the EMT. It has been shown that BMP 7 expression is down regulated in kidney failure and inflammatory or ischemic reaction [43]. The addition of exogenous BMP 7 blocks the TGF- $\beta$ signal and fibrosis process [27].

TNF- $\alpha$ (tumor necrosis factor $\alpha$ ) [44]: it is produced mainly by monocytes, macrophages, $\mathrm{T}$ cells, mesangial, glomerular and tubular renal cells. Members of the TNF superfamily of cytokines regulate several cell responses, including proliferation, differentiation, and apoptosis. It also induces the synthesis and secretion of other cytokines. TWEAK (TNF like weak inducer of apoptosis), a member of the TNF family, may promote cell death,but it also modulates cell proliferation, inflammation, and angiogenesis in renal tubular cells in the presence of pro inflammatory cytokines. JAK/STAT (Janus kinase / Signaling transducers and activation of transcription) [45]:

Protein pairs that rapidly and efficiently transduce signalling activated by the binding of cytokines such as IL6 and G-protein. Exposure to elevated glucose concentrations results in activation of JAK2/STAT signalling in a variety of cell types as well as in the renal cortex of rodents with early diabetic nephropathy. This intracellular mechanism regulates gene expression of pro inflammatory mediators and cell differentiation. Atherosclerosis and arterial hypertension could be influenced by JAK/STAT 
signal and can induce TGF- $\beta$, fibronectin and collagen type IV production. SOCS (suppresor of cytokine signalling) is the main JAK/STAT inhibitor.

CTGF [46]: a member of the C-terminal cystein-rich proteins family of early response genes. CTGF increases other cytokines and chemokines expression such as MCP 1 (Monocyte chemoattractant protein-1), RANTES (regulated on activation normally T cell expressed and secreted) IL6, interferon $\alpha$; and it also reduces anti-inflammatory signals such as IL10. Finally CTGF activates NF- $\kappa$ B pathway and in the diabetic kidney, elevated CTGF expression co-localizes with sites of EMT in the kidney.

$\mathrm{NF}-\kappa \mathrm{B}[47,48]$ : a family of pleiotropic transcription factors that integrate a network of extracellular signalling pathways, resulting in the transcriptional regulation of hundreds of genes related to inflammation, immunity, apoptosis, cell proliferation and differentiation. NF- $\mathrm{kB}$ belongs to Rel family proteins. Activation of NF- $\mathrm{\kappa B}$ plays a role in various chronic kidney diseases associated with inflammation and fibrosis, and inhibition of NF- $\kappa B$ signalling effectively attenuates renal injury in experimental animals' models. NF- $\mathrm{\kappa B}$ is normally held in cytoplasm of unstimulated cells in an inactive form born to an inhibitory protein IKB. Many inflammatory genes, cytokines, glucose and viruses have joining areas to NF- $\kappa \mathrm{B}$.

VEGF (Vascular endothelial growth factor) [49,50]: VEGF family are the most critical regulator of the development of the vascular system and commonly is overexpressed in a variety of human solid tumors. It also regulates nitric oxide synthase. It has been implicated in endothelium and podocyte abnormalities in diabetic nephropathy. In CKD, VEGF levels are moody and have different implications: a deficiency decreases angiogenesis and increases apoptosis [22] but an increase could unleash macrophages recruitment. So, both low and high VEGF levels have deleterious effects over glomerular endothelium.

Leptin / adiponectin [51,52]: Adiponectin is a protein encoded by the gene protein apM1, it increases insulin sensivity and has anti-inflammatory and anti-atherogenic actions. Leptin is considered proatherogenic and fibrogenic, stimulates renal endothelial cells and causes increased production of TGF- $\beta$ and collagen type IV. Leptin also presents a vasodilator nitric oxidedependent effect but that counteracts with rest of its actions. Both proteins increase in CKD.

Calciprotein Particles (CPP): colloidal complexes calcium apatite particles in serum. Presence of CPPs carries a proinflammatory process in endothelium [53]. In CKD, CPPs levels show a correlation between proinflammatory cytokines and all mortality causes [48].

Other signals [25]: MCP1 (recruitmonocytes and macrophages in kidney inflammation process), AGEs (advanced glycation end prodcuts), B catenin (causes an important nephrin inhibition: proteinuria [11] oncostatin $\mathrm{M}$, lipid renal accumulation which could inducing TGF- $\beta$ expression, IL6 and 18, renin angiotensin aldosterone system (angiotensin II increases proinflammatory and profibrotic cytokines expression [54]).

\section{Anti fibrotic Treatment. Role of Vitamin D}

There is no $100 \%$ efficient treatment against fibrosis. Then we point out some molecules that have demonstrated a beneficial effect to this level:

Vitamin D and analogues: Vitamin D and analogues have an important effect over fibrosis process. We sum up some vitamin D and analogues effects against fibrosis [55-60]:

- Inhibition renin gene.

- Inhibition RANTES (regulated on activation normally T cell expressed and secreted) expression via antagonizing NF- $\kappa B$ activity.

- Suppress TGF- $\beta$ expression as well as block directly TGF $\beta$ induced EMT and ECM proteins

- Suppress TNF- $\alpha$

- Increase endothelin B receptor and nitric oxide.

- Decrease proteinuria.

- Vitamin D analogues do not stimulate CBFA signal 1 (core binding factor alpha) in endothelium.

- $\quad$ Rise BMP 7 levels.

It has been shown that expression of vitamin $\mathrm{D}$ receptor is decreased in different fibrosis models $[61,62]$. In chronic kidney disease experimental models, vitamin $\mathrm{D}$ and analogues have shown to reduce mesangial expansion and fibronectin storage in tubulointerstitial area, prevent the expression of profibrotic growth factors (TGF- $\beta$, PAI-1 (plasminogen inhibitor 1 ) and CTGF) and infiltration of $\mathrm{CD} 68+$ and expression of proinflammatory cytokines and NF- $\kappa B[63,64]$. Tan, et al. [65] investigated the effects of PRCT (subcutaneous injections 0.1-0.3 mcg / kg) on obstructive nephropathy in mouse model. Compared with vehicle controls, PRCT significantly attenuated renal interstitial fibrosis, and repressed mRNA expression of fibronectin and type I and type III collagens. It also suppressed renal TGF- and its type I receptor expression, restored vitamin D receptor abundance, and inhibited cell proliferation and apoptosis after obstructive injury At the same time, human proximal tubular epithelial cells were incubated with various concentrations of PRCT in the absence or presence of TGF- $\beta$ (2ng/ mL); PRCT inhibited the TGF- $\beta$ mediated Snail induction in vitro [66]. Same investigators developed a mice mice obstructive nephropathy: They subdivided animals into five groups: sham control, obstructive nephropathy vehicle control, obstructive nephropathy mice receiving 0.3 $\mathrm{mg} / \mathrm{kg}$ paricalcitol, obstructive nephropathy mice receiving 3 $\mathrm{mg} / \mathrm{kg}$ trandolapril, obstructive nephropathy mice receiving $0.3 \mathrm{mg} / \mathrm{kg}$ paricalcitol and $3 \mathrm{mg} / \mathrm{kg}$ trandolapril. After 7 days PRCT inhibited the expression and accumulation of fibronectin and type I and type III collagen, suppressed $\alpha$ SMA, vimentin, and Snail1, RANTES and TNF- $\alpha$ expression, and reduced collagen [66]. Combination therapy led to a more profound inhibition of all fibrosis parameters [67]. Similar results are found in the following studies: J Yang, et al. [67] and Bottinger, et al. [68]. 
It remains to be determined whether TGF- $\beta$ inhibition is cause or consequence of fibrosis reduction due to vitamin D and its analogues $[61,69]$. Vitamin D, and its analogues, directly block TGF- $\beta$ effects and repress the Snail. Other studies suggest that vitamin a D and its analoues are due to renin and NF- $\kappa B$ which leash to an anti-inflammatory and ant fibrotic effects $[61,70]$. Vitamin D supplementation may be a rational strategy to prevent fibrosis and EMT.

\section{Other treatments}

BMP 7: It has been shown that BMP 7 down regulates fibrotic process in different kidney, liver and cardiac disease models [7073]. There is an equilibrium between BMP 7 and TGF- $\beta$ in control of EMT process [42]. Both molecules bind to threonine kinase serine type I receptors (ALK receptors) that triggers intracellular signals mediated by different Smad proteins. In peritoneal MCs it has been shown that BMP 7 reverses EMT [73].

Mammalian target of rapamycin (mTOR) inhibitors [74]: mTOR signal results in hypoxia-inducible factor 1 (HIF-1)) and ROR $\gamma \mathrm{t}$ (transcription factor retinoic acid-related orphan receptor $\gamma$ t) activation, this event causes IL17 and 23.

Peroxisome proliferator-activated receptor $\gamma$ (PPAR): it inhibits THC17 differentiation by blocking Stat 3 cascade, and provokes a RORyt down regulation and a decrease in Il 17 production [76]. It also increases Il 10 levels, at least intraperitoneal [76]. COX-2 inhibitors (Celecoxib) [77]: it is considered an inflammatory inhibitor in animal models (mice).

Other treatments: Inhibition of the renin angiotensin aldosterone system, NF- $\kappa$ B, blocking TGF- $\beta($ SnoN and Ski block Smad signal), SOCS (inhibitor of JAK / STAT signal), pentoxifylline.

\section{Conflict of Interest}

The authors declare no conflict of interest. None

\section{References}

1. http://www.carloshaya.net/biblioteca/contenidos/docs/nefrologia/ predialisis/pacodiez.PDF.

2. Hernando Avendaño y colaboradores. Nefrología Clínica. 3ạaedición Panamericana. 2008;21.

3. Strutz F, Zeisberg M. Renal Fibroblasts and myofibroblast in chronic kidney disease. J Am Soc Nephrol. 2006;17:2992-2998.

4. Brosius F C. New insights into the mechanism of fibrosis and sclerosis in diabetic nephropathy. Rev Endocr Metab Disord. 2008;9(4):245-54. doi: 10.1007/s11154-008-9100-6.

5. Navarro JF, Mora C. The role of inflammatory cytokines in diabetic nephropathy. J Am Soc Nephrol. 2008;19: 433-422. doi: 10.1681/ ASN.2007091048.

6. Zeisberg E, Potenta S, Sugimoto H, Zeisberg M, Kalluri R.. Fibroblast in kidney fibrosis emerge via endothelial to mesenghymal transition. J Am Soc Nephrol. 2008;19:2282-2287. doi: 10.1681/ASN.2008050513.

7. Inoue T, Umezawa A, Takenaka T, Suzuki H, Okada H, The contribution of epithelial-mesenchymal transition to renal fibrosis differs among kidney disease model. Kidney Int. 2015;87(1):233-8. doi: 10.1038/ ki.2014.235.
8. Kendrick J, Choncol M. The role of phosphorus in the development and progression of vascular calcification. Am J Kidney Dis. 2011;58(5):826834. doi: 10.1053/j.ajkd.2011.07.020.

9. Boor P, Floegel J. The renal (myo-)Fibroblast: a heterogeneous group of cells. Nephrol. Dial. Transplant 2012;27 (8): 3027 3036. Doi: $10.1093 /$ ndt/gfs296.

10. Nightingale J, Patel S, Suzuki N, Buxton R, Takagi K, Suzuki J. et al. Oncostatin M, A cytokine released by activated. mononuclear cells, induces epithelial cell-myoFibroblast transdifferentiation via Jak/Stat pathway activation. J Am Soc Nephrol. 2004;15:21-32.

11. Liu Y. New insights into epithelial-mesenchymal transition in kidney fibrosis. J Am Soc Nephrol. 2010;21:212-222. doi: 10.1681/ ASN.2008121226.

12. Yáñez-Mó M1, Lara-Pezzi E, Selgas R, Ramírez-Huesca M, DomínguezJiménez C, Jiménez-Heffernan JA, et al. Peritoneal dialysis and epithelial to mesenchymal transition of mesothelial cells. $\mathrm{N}$ Engl J Med. 2003;348:403-413.

13. Batlle E, Sancho E, Francí C, Domínguez D, Monfar M, Baulida J, et al. The transcription factor Snail is a represor of E-cadherin gene expresión in epithelial tumour cells. Nat Cell Biol. 2000;2:84-89.

14.Williams J D, Craig K J, Topley N, Von Ruhland C, Fallon M, Newman GR, et al. Morphologic changes in the peritoneal membrane of patients with renal disease. J Am Soc Nephrol. 2002;13(2):470-9.

15. Aroeira LS1, Lara-Pezzi E, Loureiro J, Aguilera A, Ramírez-Huesca M, González-Mateo G, et al. Cyclooxygenase-2 mediates dialysateinduced alterations of the peritoneal membrana. J Am Soc Nephrol. 2009;20:582-592. doi:10.1681/ASN.2008020211.

16. Waite JC, Skokos D. Th17 response and inflammatory autoimmune diseases. Int J Inflam. 2012;2012:819-467.doi: 10.1155/2012/819467.

17. Ivanov II, McKenzie BS, Zhou L, Tadokoro CE, Lepelley A Lafaille JJ, et al. The orphan nuclear receptor ROR $\gamma$ t directs the differentiation program of proinflammatory IL-17+ T helper cells. Cell 2006;126(6):1121-1133.

18. Harris TJ, Grosso JF, Yen HR, Xin H, Kortylewski M, Albesiano E, et al. An in vivo requirement for STAT3 signaling in TH17 development and TH17-dependent autoimmunity. Journal of Immunology. 2007;179(7):4313-4317.

19. Liappas G, Gónzalez-Mateo GT,Majano P, Sánchez-Tomero JA, RuizOrtega M, Rodrigues Díez R, et al. T helper 17/regulatory T cell balance and experimental models of peritoneal dialysis-induced damage. Biomed Res Int. 2015;416480. doi: 10.1155/2015/416480.

20. Su Mi, Zhe Li, Hong-Zhen Yang, Hong Liu, Jia-Ping Wang, et al. Blocking IL-17A promotes the resolution of pulmonary inflammation and fibrosis via TGFbeta1-dependent and -independent mechanisms. Journal of Immunology 2011;187(6):30033014.

21.Veldhoen M, Hocking RJ, Atkins CJ, Locksley RM, Stockinger B. TGF $\beta$ in the context of an inflammatory cytokine milieu supports de novo differentiation of IL-17-producing $\mathrm{T}$ cells. Immunity. 2006;24(2):179189.

22. Böttinger E, Bitzer M. TGF $\beta$ signaling in renal disease. J Am Soc Nephrol. 2002;13:2600-2610.

23. Schiffer M, Bitzer M, Roberts IS, Kopp JB, ten Dijke P, Mundel P, et al. Apoptosis in podocytes induced by TGF-beta and Smad7. J Clin Invest. 2001;108:807-816.

24. Hruska K, Mathew S, Saab G. Bone morphogenetic proteins in vascular calcification. Circulation Research. 2005;97(2):105-114. 
25.Johnson RJ: Cytokines, growth factors and renal injury: where do we go now? Kidney Int Suppl 1997;63:S2-S6.

26. Oldfield MD, Bach LA, Forbes JM, Nikolic-Paterson D, McRobert A, Thallas V, et al. Advanced glycation end products cause epithelialmyofibroblast transdifferentiation via the receptor for advanced glycation end products (RAGE). J Clin Invest. 2001;108(12):1853-63.

27. Loureiro J, Schilte M, Aguilera A, Albar-Vizcaíno P, Ramírez-Huesca M, Pérez-Lozano ML, et al. BMP 7 blocks mesenchymal conversion of mesothelial cells and prevents peritoneal damage induced by dialysis fluid exposure. Nephrol Dial Transplant. 2010;25(4):1098-108. doi: $10.1093 / \mathrm{ndt} / \mathrm{gfp} 618$

28. Wan M, LI C, Zhen G, Jiao K, He W, Jia X, et al. Injury-activated TGF beta controls mobilization of MSCs for tissue remodeling. Stem Cells. 2012;30:2498-2511.

29. Wojakowski W, Landmesser U, Bachowski R, Jadczyk T, Tendera M. Mobilization of stem and progenitor cells in cardiovascular diseases. Leukemia. 2011;26:23-33. doi: 10.1038/leu.2011.184.

30. Piek E, Moustakas A, Kurisaki A, Heldin C H, Ten Dijke P. Proteínas TGF beta de tipo receptor E/ALK-5 y Smad median la transdiferenciación epitelio mesenquimal en células epiteliales mamarias (NMuMG). J Cell Sci 1999;112(24):4557-4568.

31. Larisch S, Yi Y, Lotan R, Kerner H, Eimerl S, Tony Parks W, A novel mitochondrial septin-like protein, ARTS, mediates apoptosis dependent on its P-loop motif. Nat Cell Biol 2000;2:915-921.

32. Yang J, Zhang X, Liu Y. Downregulation of Smad transcriptional corepressors SnoN and Ski in the fibrotic kidney: an amplification mechanism for TGF- 1 signaling. J Am Soc Nephrol. 2003;14:31673177.

33. Valdivielso JM. Calcificación vascular: tipos y mecanismos. Nefrología 2011;31(2):142-147.

34. Wang EA, Rosen V, D’Alessandro JS, Bauduy M, Cordes P, Harada T, et al. Recombinant human bone morphogenetic protein induces bone formation. Proc Natl Acad Sci USA. 1990;87:2220-2224.

35. Schluesener HJ, Meyerman R. Immunolocalization of BMP-6, a novel TGF related cytokine, in normal and atherosclerotic smooth muscle cells. Atherosclerosis. 1995;113:153-156.

36. Dhore CR, Cleutjens JP, Lutgens E, Cleutjens KB, Geusens PP, Kitslaar PJ, et al. Differential expression of bone matrix regulatory proteins in human atherosclerotic plaques. Arterioscler Thromb Vasc Biol. 2001;21:1998-2003.

37. Fukui N, Zhu Y, Maloney WJ, Clohisy J, Sandell LJ. Stimulation of BMP-2 expression by pro-inflammatory cytokines IL-1 and TNF__ in normal and osteoarthritic chondrocytes. J Bone and Joint Surg. 2003;85:5966.

38. Vukicevic S, Kopp JB, Luyten FP, Sampath TK. Induction of nephrogenic mesenchyme by osteogenic protein 1 (bone morphogenetic protein 7). Proc Natl Acad Sci U S A. 1996;93:9021 9026.

39. Vukicevic S, Kopp JB, Luyten FP, Sampath TK. Expression of bone morphogenetic protein-7 mRNA in normal and ischemic adult rat kidney. Amer J Physiol. 1999;276:F382-F389.

40.Wang S, Chen Q, Simon TC, Strebeck F, Chaudhary L, Morrissey J, et al. Bone morphogenetic protein-7 (BMP-7), a novel therapy for diabetic nephropathy. Kidney Int. 2003;63:2037-2049.

41. Dorai H, Vukicevic S, Sampath TK. Bone morphogenetic protein-7 (osteogenic protein-1) inhibits smooth muscle cell proliferation and stimulates the expression of markers that are characteristic of SMC phenotype in vitro. J Cellular Physiol. 2000;184:37-45.

42. Dorai H, Sampath TK. Bone morphogenetic protein-7 modulates genes that maintain the vascular smooth muscle cell phenotype in culture. J Bone and Joint Surg. 2001;83:S70-S78.

43. Kalluri R, Weinberg RA. The basics of epithelial-mesenchymal transition. J. Clin. Invest. 2009;119(6):1420-1428. doi: 10.1172/ JCI39104.

44.Locksley RM, Killeen N, Lenardo MJ. The TNF and TNF receptor superfamilies: integrating mammalian biology. Cell. 2001;104:487501.

45. Ortiz-Muñoz G, Lopez-Parra V, Lopez-Franco O, Fernandez-Vizarra P, Mallavia B, Flores C, etal. Suppressors of cytokine signaling abrogate diabetic nephropathy. J Am Soc Nephrol. 2010;21:763-772.

46. Sánchez-López E, Rayego S, Rodrigues-Díez R, Rodriguez JS, RodriguesDíez R, Rodríguez-Vita J, et al. CTGF Promotes inflammatory cell infiltration of the renal interstitium by activating NF-kB. J Am Soc Nephrol. 2009;20:1513- 1526. doi: 10.1681/ASN.2008090999.

47. Massy ZA, Guijarro C, O’Donnell MP, Kim Y, Kashtan CE, Egido J, et at. The central Role of nuclear Factor-kB in mesangial cell activation. Kidney Int. 1999;56(71):76-79. 1999.

48. Sanz AB, Sanchez-Niño MD, Ramos AM, Moreno JA, Santamaria B, Ruiz-Ortega M, et al. NF-кB in Renal Inflammation. J Am Soc Nephrol. 2010;21:1254-1262. doi: 10.1681/ASN.2010020218.

49. Kuro-OM. A phosphate-centric paradigm for pathophysiology and therapy of chronic kidney disease. Kidney Int Supplements. 2013;3:420-426.

50. Nakagawa T, Sato W, Glushakova O, Heinig M, Clarke T, CampbellThompson M, et al. Diabetic endotelial nitric oxide synthase knockout mice develop advanced diabetic nephropathy. J Am Soc Nephrol. 2007; 18:539-550.

51.Yang AH, Huang SW, Chen JY, Lin JK, Chen CY. Leptin augments myofibrobasltic conversion and fibrogenicactivity of human peritoneal mesothelialcells: a functional implication for peritoneal fibrosis. Nephol Dial Transplant. 2007;22:756-762.

52.Teta D, Maillard M, Halabi G, Burnier M. The leptin/adiponectin ratio: potential implications for peritoneal dialysis. Kidney Int. 2008;73:S112-S118. doi: 10.1038/sj.ki.5002611.

53. Smith ER, Hanssen E, McMahon LP, Holt SG. Fetuin-A-containing calciprotein particles reduce mineral stress in the macrophage. PLoS ONE. 2013;8(4): e60904. doi: 10.1371/journal.pone.0060904.

54. Ix JH, De Boer IH, Peralta CA, Adeney KL, Duprez DA, Jenny NS, et al. Serum phosphorus concentrations and arterial stiffness among individuals with normal kidney function to moderate kidney disease in MESA. Clin J Am Soc Nephrol. 2009;4:609-615. doi: 10.2215/ CJN.04100808.

55. Rojas-Rivera J, De La Piedra C, Ramos A, Ortiz A, Egido J. The expanding spectrum of biological actions of vitamin D. Nephrol. Dial. Transplant. 2010;25(9):2850-2865. doi: 10.1093/ndt/gfq313.

56. Agarwal R, Acharya M, Tian J, Hippensteel RL, Melnick JZ, Qiu P, Williams L, et al. Antiproteinuric effect of oral paricalcitol in chronic kidney disease. Kidney Int. 2005;68:2823-2828.

57. Shroff R, Long DA, Shanahan C. Mechanistic insights into vascular calcification in CKD. J Am Soc Nephrol. 2013;24: 179-189. oi: 10.1681/ ASN.2011121191. 
58. Kendrick J, Cheung AK, Kaufman JS, Greene T, Roberts WL, Smits G, et al. Associations of plasma 25 Hydroxyvitamin D and 1,25-Dihydroxyvitamin D concentrations with death and progression to maintenance dialysis in patients with advanced kidney disease. Am J Kidney Dis. 2012;60(4):567-75. doi: 10.1053/j.ajkd.2012.04.014.

59. Yuan W, Pan W, Kong J, Zheng W, Szeto FL, Wong KE, et al. 1 , 25-Dihydroxyvitamin D3 suppresses renin gene transcription by blockingthe activity of the cyclic AMP response element in the renin gene promoter. The Journal of Biological Chemistry 2007;41(282):29821-29830.

60. Oh J, Weng S, Felton SK, Bhandare S, Riek A, Butler B, et al. 1, $25(\mathrm{OH})_{2}$ vitamin $\mathrm{D}$ inhibits foam cell formation and supresses macrophage cholesteol uptake in patients with type 2 Diabetes Mellitus. Circulation 2009;25:687-698. doi: 10.1161/CIRCULATIONAHA.109.856070.

61. Ng YY, Huang TP, Yang WC, Chen ZP, Yang AH, Mu W, et al. Tubular epithelialmyofibroblast transdifferentiation in progressive tubulointerstitial fibrosis in 5/6 nephrectomized rats. Kidney Int. 1998;54:864-876.

62. Yanagisawa J, Yanagi Y, Masuhiro Y, Suzawa M, Watanabe M, Kashiwagi $\mathrm{K}$, et al. Convergence of transforming growth factor-beta and vitamin D signaling pathways on SMAD transcriptional coactivators. Science. 1999;283:1317-1321.

63. Tian J, Liu Y, Williams LA, de Zeeuw D. Potential role of active vitamin $D$ in retarding the progression of chronic kidney disease. Nephrol Dial Transplant. 2007;22:321-328.

64. Wang XX, Jiang T, Levi M. Nuclear hormone receptors in diabetic nephropathy. Nat Rev Nephrol. 2010;6:342-351.

65. Tan X, Li Y, Liu Y. Paricalcitol attenuates renal interstitial fibrosis in obstructive nephropathy. J Am Soc Nephrol. 2006. 17;3382-3393.

66. Tan X, He W, Liu Y. Combination therapy with paricalcitol and trandolapril reduces renal fibrosis in obstructive nephropathy. Kidney Int. 2009;76(12):1248-1257.

67. Yang J, Liu Y. Dissection of key events in tubular epithelial to myofibroblast transition and its implications in renal interstitial fibrosis. Am J Pathol. 2001;159:1465-1475.

68. Bottinger EP, Bitzer M. TGF-beta signaling in renal disease. J Am Soc Nephrol. 2002;13:2600-2610.
69.Xiao HQ, Shi W, Liu SX, Zhang B, Xu LX, Liang XL, et al. Podocyte injury is suppressed by 1,25-dihydroxyvitamin D via modulation of transforming growth factor- $\beta 1 /$ bone morphogenetic protein-7 signalling in puromycin aminonucleoside nephropathy rats. Clin Exp Pharmacol Physiol. 2009;36:682-689.

70. Yang J, Liu Y. Blockage of tubular epithelial to myofibroblast transition by hepatocyte growth factor prevents renal interstitial fibrosis. J Am Soc Nephrol. 2002;13:96-107.

71. Mortier S, De Vriese AS, McLoughlin RM, Topley N, Schaub TP, PasslickDeetjen J, et al. Effects of conventional and new peritoneal dialysis fluids on leukocyte recruitment in the rat peritoneal membrane. J Am Soc Nephrol, 2003;14:1296-1306.

72. Musi B, Carlsson O, Rippe A, Wieslander A, Rippe B . Effects of acidity, glucose degradation products, and dialysis fluid buffer choice on peritoneal solute and fluid transport in rats. Perit Dial Int. 1998;18:303-310.

73. Pecoits-Filho R, Stenvinkel P, Wang AY, Heimburger O, Lindholm B. Chronic inflammation in peritoneal dialysis: the search for the holy grail? Perit Dial Int. 2004;24:327-339.

74. Ikejiri A, Nagai S, Goda N, Kurebayashi Y, Osada-Oka M, Takubo K, et al. Dynamic regulation of Th17 differentiation by oxygen concentrations," International Immunology. 2012;24(3):137-146.

75. Klotz L, Burgdorf S, Dani I, Saijo K, Flossdorf J, Hucke S, et al. The nuclear receptor PPARgamma selectively inhibits Th17 differentiation in a T cell-intrinsic fashion and suppresses CNS autoimmunity. The Journal of Experimental Medicine. 2009;206(10):2079-2089. doi:10.1084/ jem.20082771.

76. Sandoval P, Loureiro J, González-Mateo G, Pérez-Lozano ML, Maldonado-Rodríguez A, Sánchez-Tomero JA, et al. PPAR-gamma agonist rosiglitazone protects peritoneal membrane from dialysis fluid-induced damage. Laboratory Investigation. 2010;90(10):15171532.

77. Aroeira LS, Lara-Pezzi E, Loureiro J, Aguilera A, Ramírez-Huesca M, González-Mateo G, et al. Cyclooxygenase-2 mediates dialysateinducedalterations of the peritoneal membrane. Journal of the American Society of Nephrology. 2009;20(3):582-592. doi: 10.1681/ ASN.2008020211. Epub 2009 Jan 21. 